\title{
Waste Heat Recovery from Iron Production by Using Magnesium 0xide/Water Chemical Heat Pump as Thermal Energy Storage
}

\author{
Odtsetseg MYAGMARJAV, ${ }^{1) *}$ Junichi RYU ${ }^{2)}$ and Yukitaka KATO ${ }^{1)}$ \\ 1) Department of Nuclear Engineering, Tokyo Institute of Technology, 2-12-1-N1-22, Ookayama, Meguro-ku, Tokyo, $152-8550$ \\ Japan. $\quad 2$ 2) Research Laboratory for Nuclear Reactors, Tokyo Institute of Technology, 2-12-1-N1-22, Ookayama, \\ Meguro-ku, Tokyo, 152-8550 Japan.
}

(Received on May 31, 2014; accepted on September 8, 2014)

\begin{abstract}
A heat recovery system based on thermal energy storage from the iron-making process at medium temperature range $\left(200-300^{\circ} \mathrm{C}\right)$ is presented. For an efficient waste heat recovery system the selection of suitable thermal energy storage material is essential. Accordingly, a new candidate for a chemical heat storage material used in a magnesium oxide/water chemical heat pump at medium-temperature was developed in this study. The new composite, named EML, was fabricated by mixing pure magnesium hydroxide with lithium bromide and expanded graphite, which are employed as reactivity and heat transfer enhancers, respectively. The effects of mass mixing ratios $w$ of $E G$ to $M g(O H)_{2}$ on dehydration and hydration were investigated by a thermogravimetric (TG) method, with the result that the $w$ of 0.83 was the optimal mass mixing ratio for the EML composite. Thereby the heat output capacities of the EML composite $(w=0.83$ ) were evaluated with varying reaction vapor pressure and hydration temperature. Heat output capacity per unit initial weight of the EML composite ( $w=0.83$ ) was calculated as $1168.7 \mathrm{~kJ}$ $\mathrm{kgEML}^{-1}$ at a hydration temperature of $110^{\circ} \mathrm{C}$ and reaction vapor pressure of $57.8 \mathrm{kPa}$. This value was 1.2 times higher than the corresponding heat output capacity of pure $\mathrm{Mg}(\mathrm{OH})_{2}$ powder $\left(958.5 \mathrm{~kJ} \mathrm{~kg}_{\left.\mathrm{Mg}_{(\mathrm{OH}}\right)_{2}}{ }^{-1}\right)$. This result showed that the EML composite has sufficient heat output capacity and mold-ability provided by EG for practical use in a heat exchange reactor. Thus, this composite could potentially be used as chemical heat storage materials for thermal heat storage.
\end{abstract}

KEY WORDS: iron and steel production; medium temperature waste; chemical heat storage.

\section{Introduction}

Iron and steel production is one of the most important industrial high-temperature processes and it consumes large quantities of fossil coal as a fuel, which results in global warming. In order to meet future climate targets and adjust to depletion of fossil coal availability, the development of more energy-efficient processes for the iron and steel industry is required. In this sense, thermal energy storage and conversion can increase the thermal energy efficiency by reusing the waste heat from the iron and steel making industry. There are still large amounts of waste heat at a temperature range which has not been utilized effectively, namely, between 100 and $1500^{\circ} \mathrm{C} .{ }^{1)}$ Consequently, energy recovery systems are seen as key technology for an energy efficient iron or steelmaking process.

For an efficient waste heat recovery system the selection of suitable thermal energy storage (TES) media and systems is essential. There are three kinds of TES systems, ${ }^{2)}$ namely: 1) sensible heat storage that is based on storing thermal energy by heating or cooling a liquid or solid storage medium (water, sand, molten salts, rocks), with water being the

\footnotetext{
* Corresponding author: E-mail: myagmarjav.o.aa@m.titech.ac.jp
} DOI: http://dx.doi.org/10.2355/isijinternational.55.464 cheapest option; 2) latent heat storage using phase change materials or PCMs (from a solid state into a liquid state); and 3) chemical heat storage using chemical reactions to store and release thermal energy. Previous researches ${ }^{3-6)}$ have reported that both sensible and latent heat storage systems are feasible for the waste heat recovery from iron and steelmaking processes because they greatly contribute to waste heat recovery simply, easily and economically. However, an usage of chemical reaction heat, instead of latent and sensible heat, is quite attractive from viewpoints of energy storage or transfer, energy density and connection to other industry. As far as it has been reported, there have been rare researches published on chemical heat recovery.

Therefore, we aimed to explore the waste heat recovery from iron and steel making industry by using the chemical heat storage. Chemical reactions based on solid-gas systems have demonstrated the highest potential for energy savings. In these systems, heat is stored or transferred through a reversible chemical reaction, which is carried out in a chemical heat pump (CHP). In other words, the CHP is one of the more promising technologies for use in heat storage and transformation systems. In this study, a magnesium oxide/ water $\left(\mathrm{MgO} / \mathrm{H}_{2} \mathrm{O}\right) \mathrm{CHP}$ with potentially high energy density was evaluated. The $\mathrm{MgO} / \mathrm{H}_{2} \mathrm{O} \mathrm{CHP}$ made use of a reversible chemical reaction between $\mathrm{MgO}$ and $\mathrm{H}_{2} \mathrm{O}$ and based on the 
following equilibria: ${ }^{7)}$

$$
\mathrm{MgO}(s)+\mathrm{H}_{2} \mathrm{O}(g) \leftrightarrow \operatorname{Mg}(\mathrm{OH})_{2}(s) \quad \Delta H_{\mathrm{r}}=-81.0 \mathrm{~kJ} \mathrm{~mol}^{-1}
$$

$$
\mathrm{H}_{2} \mathrm{O}(g) \leftrightarrow \mathrm{H}_{2} \mathrm{O}(l) \quad \Delta H_{\mathrm{s}}=-41.0 \mathrm{~kJ} \mathrm{~mol}^{-1}
$$

The forward reaction in Eq. (1), hydration, is exothermic and corresponds to the heat output operation of the heat pump system. The backward reaction, dehydration, is endothermic and corresponds to the heat storage operation. This type of heat pump is able to store heat at around $350^{\circ} \mathrm{C}$ through $\mathrm{Mg}(\mathrm{OH})_{2}$ dehydration and to transfer stored heat at temperatures between $110-150^{\circ} \mathrm{C}$ through $\mathrm{MgO}$ hydration. Consequently, it is expected to contribute waste heat recovery from iron and steel making processes at a temperature range which has not been utilized effectively, namely, between 200 and $300^{\circ} \mathrm{C}$. ${ }^{1)}$

Pure material, $\mathrm{Mg}(\mathrm{OH})_{2}$ is a promising chemical heat storage material for its low cost, stability, non-toxicity. ${ }^{8)}$ However, it has a low thermal conductivity. The manufacture pellets made from pure $\mathrm{Mg}(\mathrm{OH})_{2}$ (diameter of pellets = $2 \mathrm{~mm}$, average length of pellets $=10 \mathrm{~mm}$ ) provide a thermal conductivity around $0.20 \mathrm{~W} \mathrm{~m}^{-1} \mathrm{~K}^{-1}$. ${ }^{9)}$ Expanded graphite (EG) is a good choice as a high thermal conductive material ${ }^{10-12)}$ to be added into pure $\mathrm{Mg}(\mathrm{OH})_{2}$, which not only increases the thermal conductivity of the pure $\mathrm{Mg}(\mathrm{OH})_{2}$ by a factor of $\left.4-6,{ }^{9}\right)$ but also creates a kind of carrier structure that inhibits the segregation of pure material. ${ }^{13)}$ In terms of the reactivity enhancement, the $\mathrm{LiBr}$ was chosen for incorporation into the pure $\mathrm{Mg}(\mathrm{OH})_{2}$ and $\mathrm{EG}$ because of its high hygroscopic properties and large negative enthalpy changes caused by dissolution into water, since the EG is an inert material. Accordingly, a novel candidate chemical heat storage material, called EML, was developed. The composite was obtained by mixing pure $\mathrm{Mg}(\mathrm{OH})_{2}$ with $\mathrm{LiBr}$ and EG, which offer higher reactivity and thermal conductivity, respectively. ${ }^{13)}$ The contribution of $\mathrm{LiBr}$ into the EML composite not only enhances the reactivity, and improves its cycling stability, but also results in good adhesion and uniform distribution of $\mathrm{Mg}(\mathrm{OH})_{2}$ particles on the EG surface. Therefore, the effects of molar mixing ratios $\alpha$ of $\mathrm{LiBr}$ to
$\mathrm{Mg}(\mathrm{OH})_{2}$ on dehydration and hydration by a thermogravimetric (TG) method were rather studied and reported previously. ${ }^{14)}$ It was determined in a previous study ${ }^{15)}$ that the optimal molar ratio for preparation of the EML composite was $\alpha=0.10$, compared to other mixing ratios reported previously ( $\alpha=0.05,0.01,0.005$ and 0$)$.

In the present work, the effects of mass mixing ratios $w$ of EG to $\mathrm{Mg}(\mathrm{OH})_{2}$ on dehydration and hydration were explored and an optimal mass mixing ratio was determined. The influences of the reaction vapor pressure and temperature on hydration rate were investigated for the EML composite with optimized mixing ratios under the various experiential conditions. Additionally, the output capacities of the EML composite were evaluated based on the results from hydration experiments.

\section{Experimental Section}

\subsection{Experimental Apparatus and Procedure}

The dehydration and hydration reactivities of the samples were measured by the thermogravimetric method using a thermo-balance (TG-9600; Ulvac Shinku-Riko Inc.) under Ar atmosphere. Figure 1 shows the experimental apparatus used in this study. It is designed to make thermogravimetric analysis from sample mass change. The apparatus consists of main four parts: a thermobalance (TG), evaporator, water reservoir and argon (Ar) cylinder; they are linked by tubes. A sample cell is made by platinum $(\mathrm{Pt})$ with inner diameter of $7.5 \mathrm{~mm}$ and height of $10 \mathrm{~mm}$. For each experiment, a 50-mg sample was used in a Pt cell and placed in TG.

One cycle experiment consisted of a primary drying process, and dehydration, hydration, and secondary drying processes. In the primary drying process (the initial $60 \mathrm{~min}$ of the experiment), the sample was preheated at $110^{\circ} \mathrm{C}$ under a purged Ar flow of $100 \mathrm{~mL} \mathrm{~min}^{-1}$ to remove the physically adsorbed water. The temperature was then raised from 110 to $300^{\circ} \mathrm{C}$ at a heating rate of $20^{\circ} \mathrm{C} \mathrm{min}$, followed by dehydration for $120 \mathrm{~min}$. The temperature was then decreased to the hydration temperature, $T_{\mathrm{h}}, 110^{\circ} \mathrm{C}$ at $20^{\circ} \mathrm{C} \mathrm{m^{-1 }} . \mathrm{MgO}$ hydration was performed under a reaction vapor pressure, $P_{\mathrm{s}}, 57.8 \mathrm{kPa}$, achieved by mixing water supplied by a micro

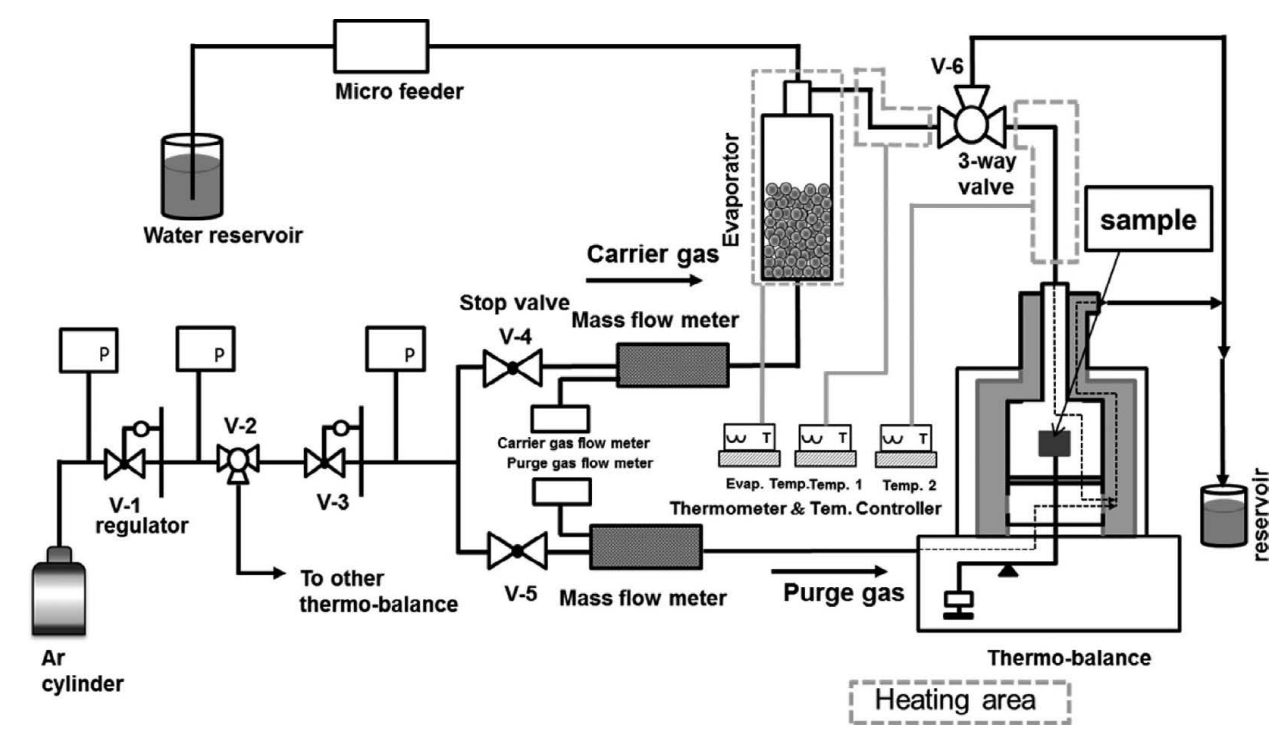

Fig. 1. Schematic diagram of experimental apparatus. 
feeder and Ar as a carrier gas. After terminating the vapor supply (140 $\mathrm{min})$, the sample was held at hydration temperature under Ar at $100 \mathrm{~mL} \mathrm{~min}^{-1}$ for $30 \mathrm{~min}$ to remove physical water from the sample during a second round of drying.

To study the influences of the reaction vapor pressure and temperature on hydration rate, the experiments had done under various conditions of $T_{\mathrm{h}}(110,130,150,170$, and $\left.200^{\circ} \mathrm{C}\right)$ and $P_{\mathrm{s}}(12.3,19.9,31.2$ and $57.8 \mathrm{kPa})$. Each measurement was conducted at least three times with different samples to determine reproducibility. The mean values of the measurements are reported as the measured results.

\subsection{Sample Preparation}

An impregnation method is used to prepare the EML composite. The EML composites $\left(\mathrm{EG}+\mathrm{Mg}(\mathrm{OH})_{2}+\mathrm{LiBr}\right)$ were prepared from pure $\mathrm{Mg}(\mathrm{OH})_{2}$ powder $(0.07 \mu \mathrm{m}$, 99.9\%; Wako Pure Chemical Industries, Ltd.), $\mathrm{LiBr} \cdot \mathrm{H}_{2} \mathrm{O}$ (99.5\%; Wako Pure Chemical Industries, Ltd.), and EG (SS3, Air Water Inc.). Aqueous $\mathrm{LiBr}$ solution was prepared from $\mathrm{LiBr} \cdot \mathrm{H}_{2} \mathrm{O}$ and ethanol. Subsequently, pure $\mathrm{Mg}(\mathrm{OH})_{2}$ powder was added to the $\mathrm{LiBr}$ solution. The solution was charged with EG. The $\mathrm{Mg}(\mathrm{OH})_{2}$ and $\mathrm{LiBr}$ impregnated in EG with an aqueous $\mathrm{LiBr}$ solution, evaporated in $30^{\circ} \mathrm{C}$ using a rotary evaporator. Finally, wet product dried at $120^{\circ} \mathrm{C}$ overnight. Two mixing ratios were defined in preparing the EML composite:

1. The molar mixing ratio $\alpha$, defined as follows:

$$
\alpha=\frac{\text { amount of } \mathrm{LiBr}[\mathrm{mol}]}{\text { amount of } \mathrm{Mg}(\mathrm{OH})_{2}[\mathrm{~mol}]}
$$

2. The mass mixing ratio $w$, defined as follows:

$$
w=\frac{\text { amount of } \mathrm{Mg}(\mathrm{OH})_{2}[\mathrm{~g}]}{\text { amounts of } \mathrm{Mg}(\mathrm{OH})_{2} \text { and } \mathrm{EG}[\mathrm{g}]}
$$

Here, $\alpha=0.0, w=1.0$ indicates pure $\operatorname{Mg}(\mathrm{OH})_{2}$ which was used as a standard reference sample. It was determined in a previous study ${ }^{15)}$ that the optimal molar mixing ratio for preparation of the EML composite was $\alpha=0.10$. Therefore, the tested samples were the EML composites with $w=0.50$, $0.67,0.75,0.80,0.83,0.86$ and 0.88 under $\alpha=0.10$. It is noted that all of tested EML composites contained the same amount of $\mathrm{LiBr}$, but the amount of EG present in the EML composite differed. For instance, $w=0.50$ means that the mass ratio $\mathrm{Mg}(\mathrm{OH})_{2}$ :EG is $1: 1$. In terms of practical applications, amounts of support materials loaded in the composite such as EG and $\mathrm{LiBr}$ should be smaller in comparison with pure $\mathrm{Mg}(\mathrm{OH})_{2}$. In this sense, $w$-values of $0.50,0.67$, $0.75,0.80,0.83,0.86$ and 0.88 corresponding to the mass ratios $\mathrm{Mg}(\mathrm{OH})_{2}: \mathrm{EG}$ of $1: 1,2: 1,3: 1,4: 1,5: 1,6: 1$ and $7: 1$ were selected and tested.

\subsection{Measured Value Definitions}

\subsubsection{Reacted Mole Fraction}

The change in mass of the sample due to dehydration and hydration as in Eq. (1) was continuously measured as a function of temperature and time using a thermo-balance. The reacted mole fraction $x[\%]$ was determined as follows:

$$
x=\left(1+\frac{\Delta m_{\mathrm{H}_{2} \mathrm{O}} \cdot \mathrm{M}_{\mathrm{Mg}(\mathrm{OH})_{2}}}{m_{\mathrm{Mg}(\mathrm{OH})_{2}} \cdot \mathrm{M}_{\mathrm{H}_{2} \mathrm{O}}}\right) \cdot 100
$$

where $\Delta m_{\mathrm{H}_{2} \mathrm{O}}[\mathrm{g}]$ is the change in the mass of the sample during the reaction, $m_{\mathrm{Mg}(\mathrm{OH})_{2}}[\mathrm{~g}]$ is the initial mass of $\mathrm{Mg}(\mathrm{OH})_{2}$ charged in the sample, and $\mathrm{M}_{\mathrm{Mg}(\mathrm{OH})_{2}}$ and $\mathrm{M}_{\mathrm{H}_{2} \mathrm{O}}$ [g mol${ }^{-1}$ ] are the molecular masses of $\mathrm{Mg}(\mathrm{OH})_{2}$ and $\mathrm{H}_{2} \mathrm{O}$, respectively. The conversion of the hydration, $\Delta x_{1}[\%]$, and the apparent change by sorption, $\Delta x_{2}[\%]$, respectively are defined as follows:

$$
\begin{aligned}
& \Delta x_{1}=x_{\mathrm{c}}-x_{0} \\
& \Delta x_{2}=x_{\mathrm{v}}-x_{\mathrm{c}}
\end{aligned}
$$

Where, the reacted mole fraction of $\mathrm{Mg}(\mathrm{OH})_{2}$ after dehydration is denoted as $x_{0}[\%]$, the reacted mole fraction of $\mathrm{MgO}$ at the end of water supply period is denoted as $x_{\mathrm{v}}[\%]$ and that of $\mathrm{Mg}(\mathrm{OH})_{2}$ after drying operation of $30 \mathrm{~min}$ is denoted as $x_{\mathrm{c}}$ [\%], respectively. Those definitions are presented in Fig. 2, the changes in the reacted mole fraction resulting from the dehydration and hydration processes for the EML composite $\left.(\alpha=0.10, w=0.50){ }^{13}\right)$

\subsubsection{Evaluation of Heat Output Capacities}

The experimental results of the hydration process were used to calculate the heat output capacity of the heat pump system. The heat output capacity was calculated from the enthalpy change of the reaction $\Delta H_{\mathrm{r}}\left[\mathrm{kJ} \mathrm{mol}{ }^{-1}\right]$ and the enthalpy change due to sorption $\Delta H_{\mathrm{s}}\left[\mathrm{kJ} \mathrm{mol}^{-1}\right]$ to determine the contribution of the each material (pure $\mathrm{Mg}(\mathrm{OH})_{2}$ and $\mathrm{LiBr}$ ) to heat production, since both hydration and sorption heat contribute to the total heat output. The heat output capacity $q_{\text {out }}$ is expressed as heat output $[\mathrm{kJ}]$ per unit initial weight of the EML composite [kg]:

$$
q_{\text {out }}=\left(\frac{-\Delta H_{\mathrm{r}}}{M_{\mathrm{Mg}(\mathrm{OH})_{2}}} \cdot \frac{\Delta x_{1}}{100}+\frac{-\Delta H_{\mathrm{s}}}{M_{\mathrm{Mg}(\mathrm{OH})_{2}}} \cdot \frac{\Delta x_{2}}{100}\right) \cdot w
$$

We assumed that the enthalpy change due to sorption of water vapor was equal to the enthalpy change due to condensation of water $\left(\Delta H_{\mathrm{s}}=\Delta H_{\mathrm{c}}=-40.7 \mathrm{~kJ} \mathrm{~mol}^{-1}\right)$.

\subsection{Kinetic Analysis of Dehydration and Hydration}

2.4.1. Dehydration Rate Analysis

The dehydration kinetics of the EML composite was dis-

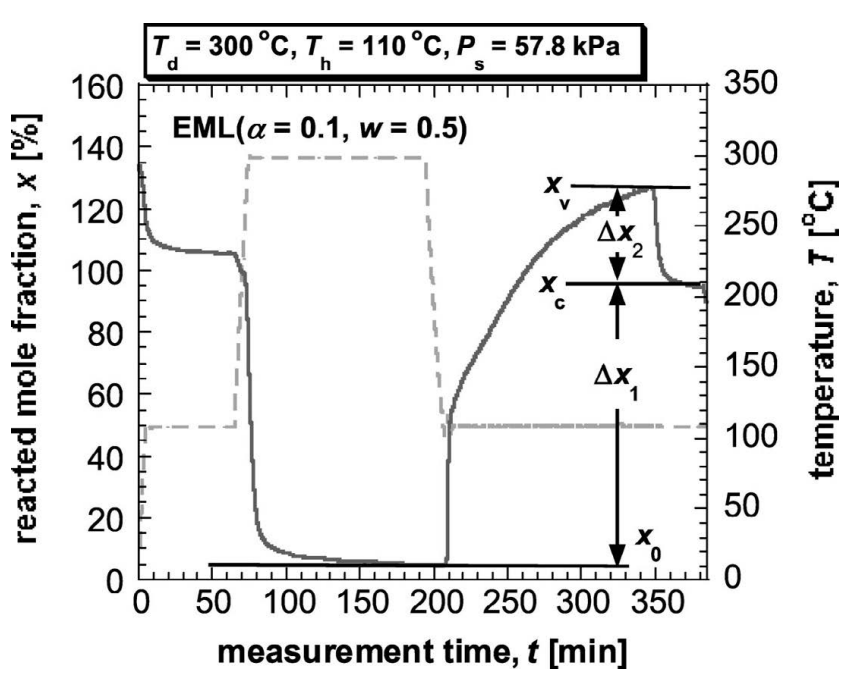

Fig. 2. Definition of conversion of the hydration process $\left(\Delta x_{1}\right)$ and the apparent change of mole reacted fraction of $\mathrm{Mg}(\mathrm{OH})_{2}$ by sorption $\left.\left(\Delta x_{2}\right){ }^{13}\right)$ 
cussed on our previous studies ${ }^{13-15)}$ and it was resulted that the dehydration kinetics could be explained by applying a first-order reaction model, which consistent with results obtained in earlier studies. ${ }^{16,17)}$ Therefore, two assumptions were made: 1) dehydration occurred homogeneously in the particles because vapor diffusivity was fast enough than chemical reaction on the particle; and 2) $\mathrm{Mg}(\mathrm{OH})_{2}$ dehydration proceeded as a first-order reaction. The first-order rate equation is written as follows:

$$
-\frac{d x_{\mathrm{d}}}{d t_{\mathrm{d}}}=k_{\mathrm{d}} x
$$

where $k_{\mathrm{d}}\left[\mathrm{s}^{-1}\right]$ and $t_{\mathrm{d}}[\mathrm{s}]$ represent the dehydration rate constant and time, respectively. The rate equation for dehydration is written in linear form as follows:

$$
\ln x_{\mathrm{d}}=-k_{\mathrm{d}} t_{\mathrm{d}}+\ln x_{0}
$$

With regard to the initial condition, $x=x_{0}$ at $t_{\mathrm{d}}=0$.

\subsubsection{Hydration Rate Analysis}

The hydration kinetics of EML composite was further examined with the aid of a shrinking unreacted core model, ${ }^{18)}$ which is identical to results obtained in earlier studies. ${ }^{19,20)}$ In particular, the experimental data for EML composite were well correlated with ash diffusion control equation, shrinking unreacted core model. ${ }^{13-15)}$ The ash diffusion control model $\left(D\left(x_{\mathrm{h}}\right)\right)$ is expressed as,

$$
D\left(x_{\mathrm{h}}\right)=1-3\left(1-x_{\mathrm{h}}\right)^{2 / 3}+2\left(1-x_{\mathrm{h}}\right)=k_{\mathrm{h}} t
$$

where $k_{\mathrm{h}}\left[\mathrm{s}^{-1}\right]$ is the hydration rate constant, and $t_{\mathrm{h}}[\mathrm{s}]$ is the hydration time.

The relation between the conversion in hydration and the reaction vapor pressure is expressed by:

$$
\Delta x_{1}=r \cdot\left(\frac{P_{\mathrm{s}}}{P_{0}}\right)^{n}
$$

By taking the natural logarithms of Eq. (12), we obtain following expression:

$$
\ln \left(\Delta x_{1}\right)=\ln (r)+n \cdot \ln \left(\frac{P_{\mathrm{s}}}{P_{0}}\right) .
$$

Here, $P_{\mathrm{s}}[\mathrm{kPa}]$ is a reaction vapor pressure, $n[-]$ is reaction coefficient, and $r[-]$ is a constant that partially depends on the rate of grain growth. Wherein, $P_{0}[\mathrm{kPa}]$ was assumed to be the atmospheric pressure $\left(P_{0}=101.325 \mathrm{kPa}\right)$. The values of $\Delta x_{1}$ was achieved after $t_{\mathrm{h}}=140 \mathrm{~min}$ of hydration. For reaction conversion obeying the reaction pressure, plots of $\ln \left(\Delta x_{1}\right)$ vs. $\ln \left(P_{\mathrm{s}} / P_{0}\right)$ yield approximately straight lines with slopes $n$.

\section{Results and Discussion}

\subsection{Effects of the Mass Mixing Ratio on Dehydration and Hydration Rate}

Figure 3 presents the effects of $w$ on the dehydration and hydration processes, wherein the first and second vertical axes indicate the reacted mole fraction, $x$, and reaction temperature, respectively, and the horizontal axis represents the measurement time. Open symbols present the data of the EML composites whilst the solid one represents the data of pure $\mathrm{Mg}(\mathrm{OH})_{2}$ powder. The colors are used to indicate the

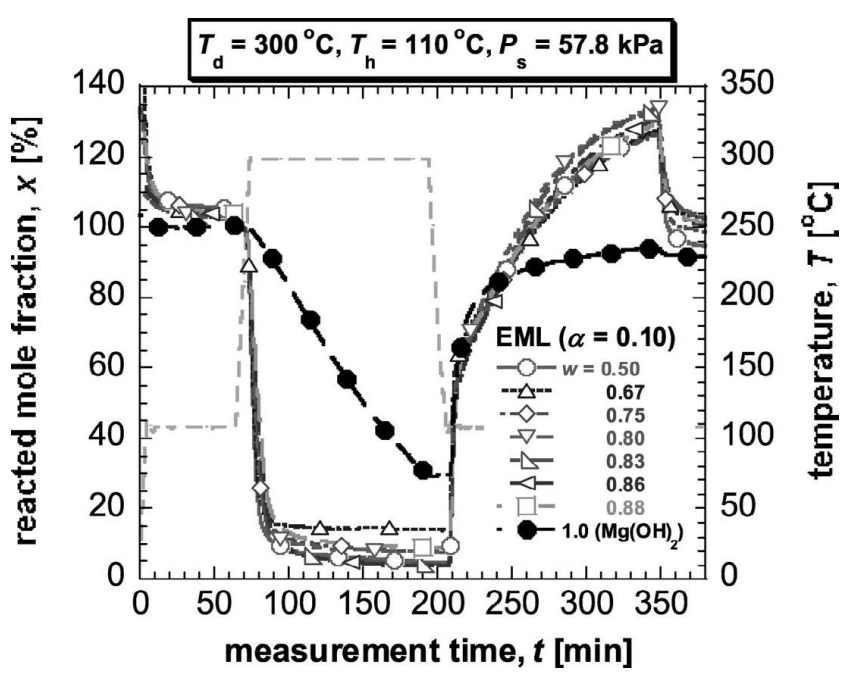

Fig. 3. Effects of the mass mixing ratio of $\mathrm{EG}$ to $\mathrm{Mg}(\mathrm{OH})_{2}, w$, on dehydration and hydration.

$w$-values: $0.50,0.67,0.75,0.80,0.83,0.86$ and 0.88 , respectively.

It can be clearly seen that all EML composites showed higher reacted mole fraction of dehydration and hydration as compared with the pure $\mathrm{Mg}(\mathrm{OH})_{2}$ powder. These enhancements in the EML composites could be attributed to the influence of $\mathrm{LiBr}$ and $\mathrm{EG}$. Nevertheless, the effect of $\mathrm{LiBr}$ was a dominant ${ }^{13}$ ) because $\mathrm{LiBr}$ is highly hygroscopic; it acted to accelerate the escape of the $\mathrm{H}_{2} \mathrm{O}$ product during dehydration and to attract $\mathrm{H}_{2} \mathrm{O}$ from the surroundings during hydration, thus increasing the reacted mole fraction. This result was also confirmed by finding no significant change in reacted mole fractions of dehydration and hydration for the EML composites with different $w$-values. It is thought that EG does not contribute the enhancement of the reactivity. Instead of that it mostly increases the thermal conductivity of the composite ${ }^{9)}$ and also improves mold ability for practical use in a heat exchange reactor due to a kind worm structure. ${ }^{13)}$ Therefore, the data in Fig. 3 was divided into main two parts: dehydration and hydration, and for each reaction the kinetic analysis was done. The kinetics of dehydration and hydration were analyzed by applying a first-order reaction model and ash diffusion control of an unreacted shrinking core model because an excellent fit were achieved for the experimental data of the EML composites via these models as reported previously. ${ }^{13,14)}$ As based on Eqs. (9) and (11), the dehydration and hydration rate constants, $k_{\mathrm{d}}$ and $k_{\mathrm{h}}$, were obtained and used to construct plots of $k_{\mathrm{d}}, k_{\mathrm{h}}$, vs. $w$ values (Fig. 4).

As it can be seen in Fig. $4, k_{\mathrm{d}}$-value decreased significantly as the $w$-value rose, which indicated that the thermal conduction played a significant role in the dehydration process. The enhancement of the heat conduction in the composite provided by EG made it possible to accelerate dehydration rate, allowing a faster and more efficient completion of the dehydration. Thus, the EML composite with $w=0.5$ corresponding mass ratio $\mathrm{Mg}(\mathrm{OH})_{2}$ :EG of 1:1 exhibited highest $k_{\mathrm{d}}$-value whilst smallest $k_{\mathrm{d}}$-value was obtained for the EML composite with $w=0.88$ corresponding mass ratio $\mathrm{Mg}(\mathrm{OH})_{2}:$ EG of $7: 1$.

In case of the hydration, the $k_{\mathrm{h}}$-value decreased when the 


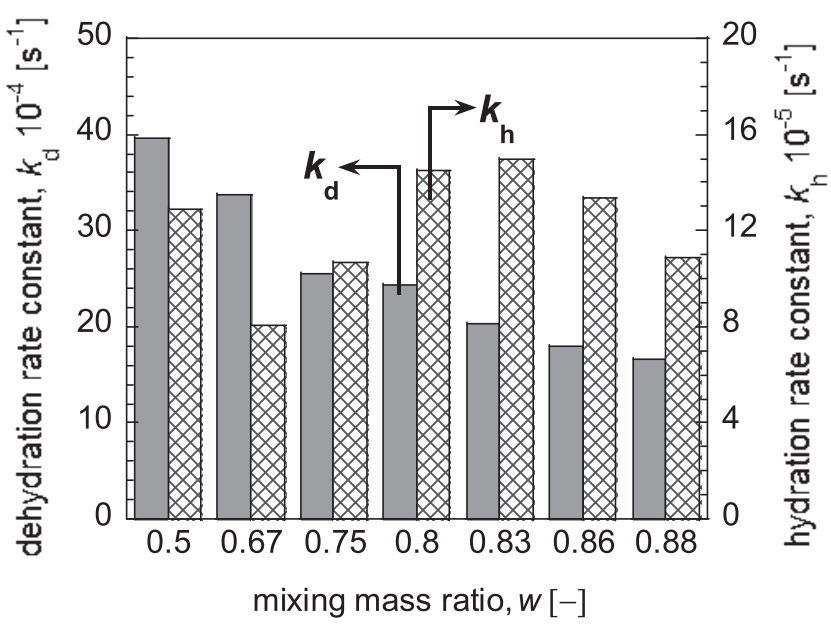

Fig. 4. Plots of $k_{\mathrm{d}}, k_{\mathrm{h}}$ Vs. $w$ for the EML composite $(\alpha=0.10)$.

$w$-value increased from 0.50 to 0.67 . It might be because of the reduction of thermal conductivity. However, the $k_{\mathrm{h}}$-value started to increase in region of $0.67 \leq w \leq 0.83$. It was assumed that the diffusion of water into the composite has been accelerated by reduction of EG amount, resulting in raise of the hydration rate. After reaching the peak, the $k_{\mathrm{h}^{-}}$ value gradually degraded again as the $w$-value rose $(0.83 \leq$ $w \leq 0.88)$. It was presumed that this reduction of the $k_{\mathrm{h}}$-value was due to the low thermal conduction even enough the vapor diffusivity. As a result, the value of $w=0.83$ corresponding to $\mathrm{Mg}(\mathrm{OH})_{2}$ :EG mass mixing ratio of $5: 1$ would be the optimal mass mixing ratio by considering hydration rate constant given in Fig. 4. Hence, it is expected that a desired heat storage material with the optimal mixing ratios would be the EML composite $(\alpha=0.10, w=0.83)$.

Preliminary measurement of thermal conductivity on the EML composite ( $\alpha=0.10, w=0.83$ ) was executed by using a Quick thermal conductivity meter (QTM500, Kyoto electronics) and hot wire method. To compare the result obtained for the EML composite with pure $\mathrm{Mg}(\mathrm{OH})_{2}$ as reference material, ${ }^{9)}$ a slab specimen of the EML composite (size $20 \times 32.6 \times 100 \mathrm{~mm}$, density of slab is $0.833 \mathrm{~g} \mathrm{~cm}^{-3}$ ) was prepared. It has been reported ${ }^{9)}$ that the thermal conductivity of pure $\mathrm{Mg}(\mathrm{OH})_{2}$ as a slab (size $20 \times 21 \times 100 \mathrm{~mm}$, density of slab is $1.00 \mathrm{~g} \mathrm{~cm}^{-3}$ ) is $0.28 \mathrm{~W} \mathrm{~m}^{-1} \mathrm{~K}^{-1}$ measured by QTM500 and hot wire method, which is same as one used in this study. The value of the thermal conductivity of the EML $(\alpha=0.10, w=0.83)$ slab was $1.91 \mathrm{~W} \mathrm{~m}^{-1} \mathrm{~K}^{-1}$. This value is 6.8 times larger than the corresponding value for pure $\mathrm{Mg}(\mathrm{OH})_{2}$ slab $\left(0.28 \mathrm{~W} \mathrm{~m}^{-1} \mathrm{~K}^{-1}\right)$. This result confirmed that the EML composite had higher thermal conductivity than one of $\mathrm{Mg}(\mathrm{OH})_{2}$ due to present of EG. Attention was now turned to the investigation of effects of reaction vapor pressure and temperature on hydration of the EML composite $(\alpha=0.10, w=0.83)$ and evaluation of reaction performances, which are discussed in subsequent sections.

\subsection{Effects of the Reaction Vapor Pressure and Tem- perature on Hydration}

To investigate the influence of the reaction vapor pressure on hydration, the hydration measurements were carried out at $12.3,19.9,31.2,47.4$ and $57.8 \mathrm{kPa}$ and a constant reaction temperature of $110^{\circ} \mathrm{C}$ for $140 \mathrm{~min}$ for the EML composite

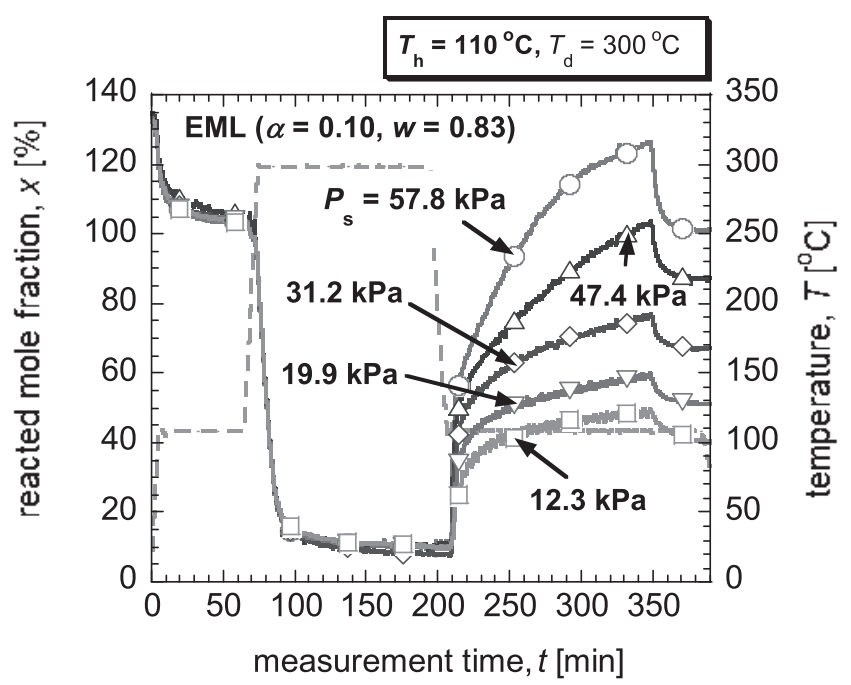

Fig. 5. Effects of vapor pressure on hydration of the EML composite $(\alpha=0.10, w=0.83)$ at $T_{\mathrm{h}}=110^{\circ} \mathrm{C}$ and $T_{\mathrm{d}}=300^{\circ} \mathrm{C}$.

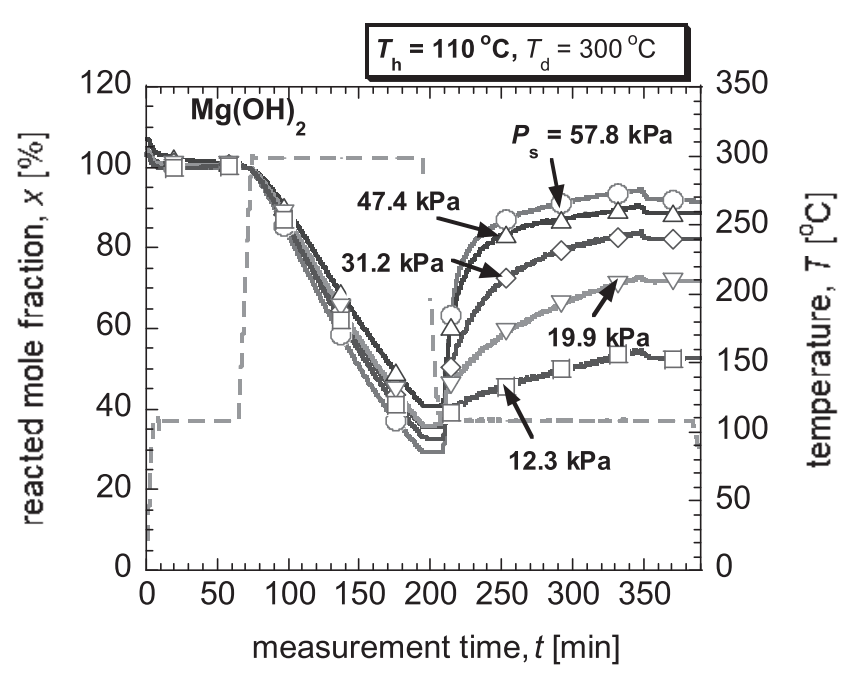

Fig. 6. Effects of vapor pressure on hydration of pure $\mathrm{Mg}(\mathrm{OH})_{2}$ powder at $T_{\mathrm{h}}=110^{\circ} \mathrm{C}$ and $T_{\mathrm{d}}=300^{\circ} \mathrm{C}$.

$(\alpha=0.10, w=0.83)$ and pure $\mathrm{Mg}(\mathrm{OH})_{2}$ powder. The results for the EML composite $(\alpha=0.10, w=0.83)$ and pure $\mathrm{Mg}(\mathrm{OH})_{2}$ powder are shown in Figs. 5 and 6, where the different symbols indicate the vapor pressure investigated. It is evident from the results that the reacted mole fraction of hydration increased with increasing vapor pressure and showed a maximum at $57.8 \mathrm{kPa}$. Higher vapor pressure results in a higher concentration of water and larger amounts of adsorbed water around the particles, accelerating the hydration rate.

The data of the EML composite and pure $\mathrm{Mg}(\mathrm{OH})_{2}$ at highest $(57.8 \mathrm{kPa})$ and lowest $(12.3 \mathrm{kPa})$ pressures, compared to other reaction pressures studied $(19.9,31.2$ and $47.4 \mathrm{kPa}$ ), were selected to build a comparison plot of hydration profiles as illustrated in Fig. 7. Herein, the ordinate and abscissa are equal to the measured mole reacted fraction of hydration, $x_{\mathrm{h}}$, and the hydration time, $t_{\mathrm{h}}$, respectively. Solid symbols represent the data of the EML composite whilst open symbols indicate the data of pure $\mathrm{Mg}(\mathrm{OH})_{2}$ powder. It is observed that $x_{\mathrm{h}}$-values of the EML composite were higher than those obtained for pure 
$\mathrm{Mg}(\mathrm{OH})_{2}$ powder at certain reaction pressures. It was confirmed that $\mathrm{LiBr}$ accelerated increase of $\mathrm{H}_{2} \mathrm{O}$, enhancing hydration reactivity, because $\mathrm{LiBr}$ is strongly hygroscopic property. The reacted mole fraction of hydration over the

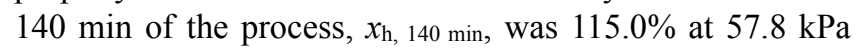
for the EML composite. This value corresponded to 1.8 times increased respect with one for pure $\mathrm{Mg}(\mathrm{OH})_{2}$ powder.

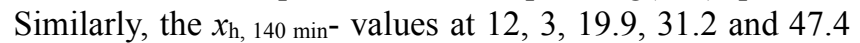
$\mathrm{kPa}$ were determined from data of the EML composite (Fig. 5) and pure $\mathrm{Mg}(\mathrm{OH})_{2}$ powder (Fig. 6), and those values were used to construct a comparison plot.

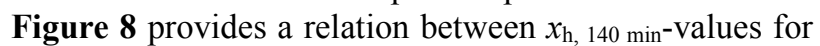
the EML composite and pure $\mathrm{Mg}(\mathrm{OH})_{2}$ powder and reaction vapor pressures, $P_{\mathrm{s}} ; 12,3,19.9,31.2,47.4$ and $57.8 \mathrm{kPa}$. It

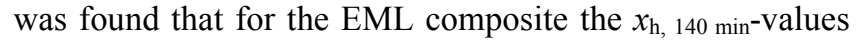
at $12.3,19.9,31.2$, and $47.4 \mathrm{kPa}$ was $39.4,49.7,68.4$, and

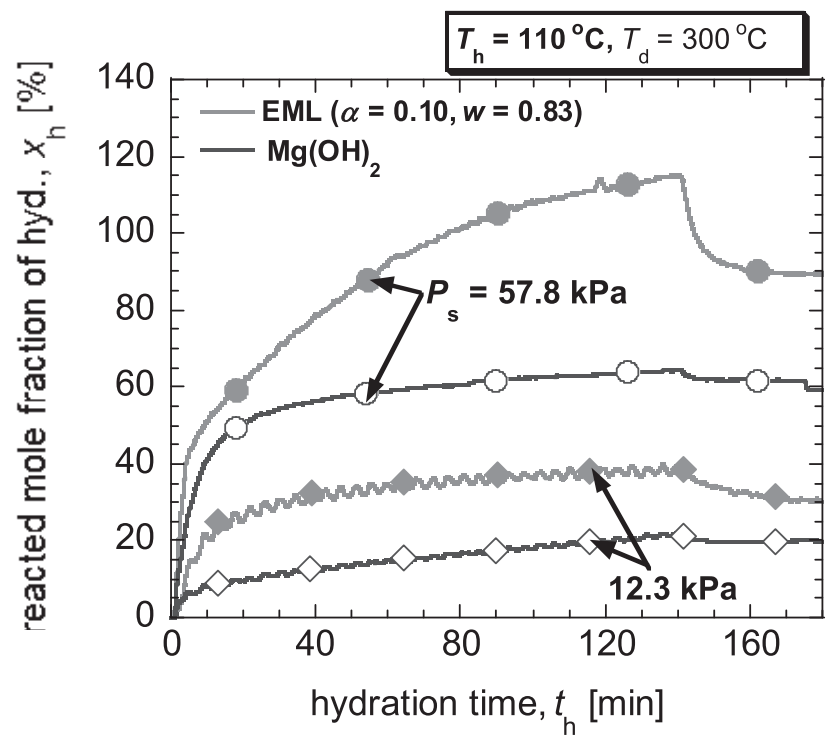

Fig. 7. Comparison of hydration profiles of the EML composite $(\alpha=0.10, w=0.83)$ and pure $\mathrm{Mg}(\mathrm{OH})_{2}$ powder at 12.3 and $57.8 \mathrm{kPa}$.

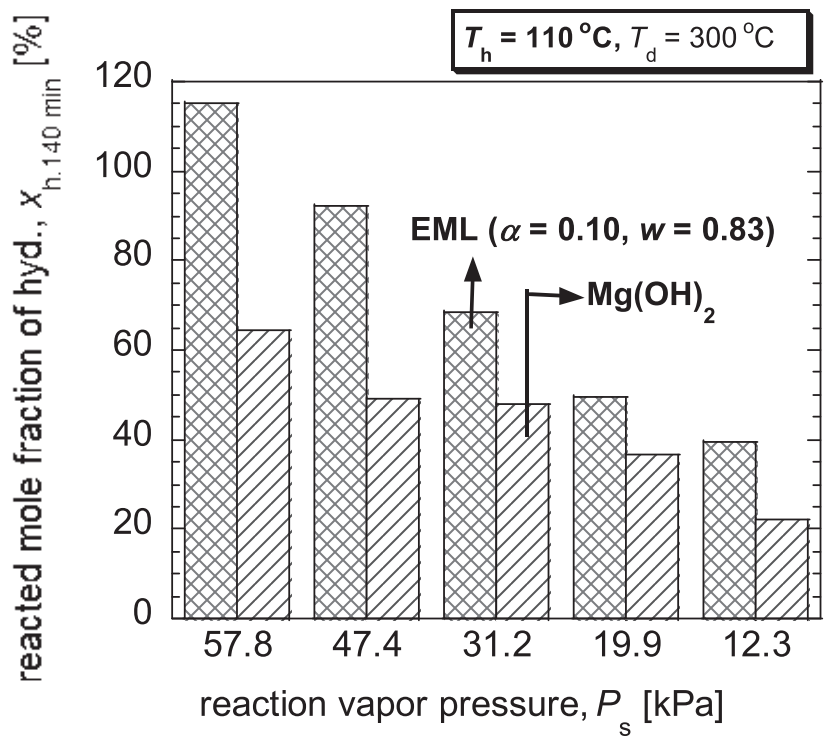

Fig. 8. Comparison of $x_{\mathrm{h}, 140 \mathrm{~min}}$ values for the EML composite ( $\alpha=$ $0.10, w=0.83)$ and pure $\mathrm{Mg}(\mathrm{OH})_{2}$ powder at $12.3,19.9$, $31.2,47.4$ and $57.8 \mathrm{kPa}$.
$92.3 \%$, respectively. These values corresponded to a 17.4 , $13.0,20.3$, and $43.0 \%$ increase in this composite by comparison with the pure $\mathrm{Mg}(\mathrm{OH})_{2}$ powder. Additionally, an interesting observation from Fig. 8 was that the hydration reactivity of the EML composite under $19.9 \mathrm{kPa}$ was equivalent to that of pure $\mathrm{Mg}(\mathrm{OH})_{2}$ powder at $47.4 \mathrm{kPa}$.

Now attention was turned to the investigation of effects of reaction temperature on the hydration. Accordingly, the hydration measurements were carried out at reaction temperatures of $110,130,150,170$ and $200^{\circ} \mathrm{C}$, respectively for 140 min under a various reaction pressure: $12.3,19.9,31.2$ and $57.8 \mathrm{kPa}$ for the EML composite $(\alpha=0.10, w=0.83)$. The temperature dependency of the hydration of the EML composite $(\alpha=0.10, w=0.83)$ at reaction vapor pressure of $57.8 \mathrm{kPa}$ and $19.9 \mathrm{kPa}$ are shown in Figs. 9 and 10. It can

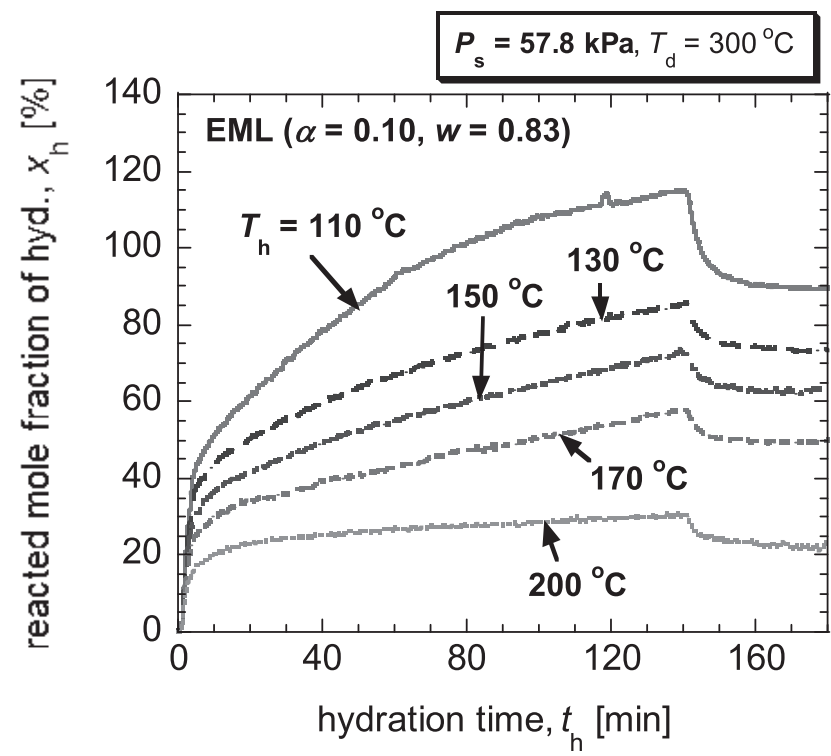

Fig. 9. Effects of reaction temperature on hydration of the EML composite $(\alpha=0.10, w=0.83)$ at $P_{\mathrm{s}}=57.8 \mathrm{kPa}$ and $T_{\mathrm{d}}=$ $300^{\circ} \mathrm{C}$.

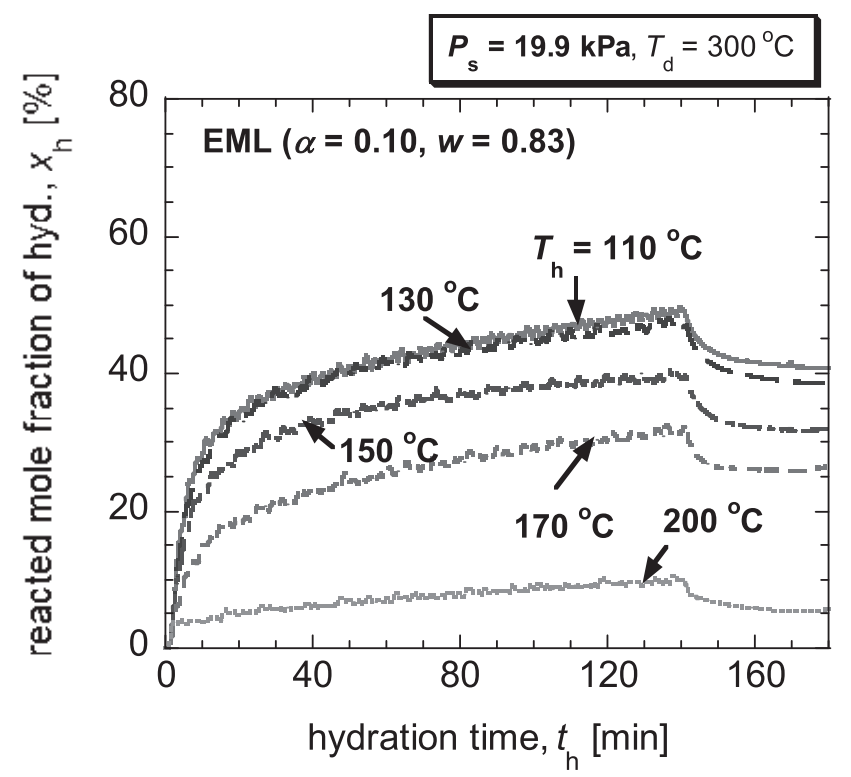

Fig. 10. Effects of reaction temperature on hydration of the EML composite $(\alpha=0.10, w=0.83)$ at $P_{\mathrm{s}}=19.9 \mathrm{kPa}$ and $T_{\mathrm{d}}=$ $300^{\circ} \mathrm{C}$. 
be seen from these figures that the mole reacted fraction of hydration increased as the reaction temperature decreased, which indicated that temperature played a significant role in the reactivity enhancement as well as reaction vapor pres-

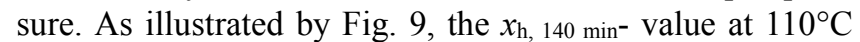
was $115.0 \%$ over $140 \mathrm{~min}$ when $P_{\mathrm{s}}=57.8 \mathrm{kPa}$. This value corresponded to a $29.4,42.3,57.3$ and $84.4 \%$ decrease for those at $130,150,170$ and $200^{\circ} \mathrm{C}$, respectively. When $P_{\mathrm{s}}$ decreased from 57.8 (Fig. 9) to $19.9 \mathrm{kPa}$ (Fig. 10), a trend of hydration profiles at $110^{\circ} \mathrm{C}$ was going to similar to one at $130^{\circ} \mathrm{C}$. Then, the $x_{\mathrm{h}, 140 \mathrm{~min}^{-}}$values attained at 110 and $130^{\circ} \mathrm{C}$ were 49.7 and $46.7 \%$. Furthermore, the hydration reactivity could be maintained at temperature of $200^{\circ} \mathrm{C}$ when the reaction vapor pressure was as low as $19.9 \mathrm{kPa}$. It was concluded that the EML composite is able to transfer the stored heat at higher hydration temperature whilst lower pressure. This observation is important for commercializing the EML composites.

To enable a fair comparison of the conversion in hydration as a function of reaction pressure, the conversion in the hydration, $\Delta x_{1}$, which defined in Fig. 2, were determined from the data at $T_{\mathrm{h}}\left(110,130,150,170\right.$ and $\left.200^{\circ} \mathrm{C}\right)$ and $P_{\mathrm{s}}$ $(12.3,19.9,31.2$ and $57.8 \mathrm{kPa})$. Similarly, the apparent change by sorption, $\Delta x_{2}$, was determined. Then, the values of $\Delta x_{1}$ and $\Delta x_{2}$ are summarized in Table 1. Figure 11 pres-

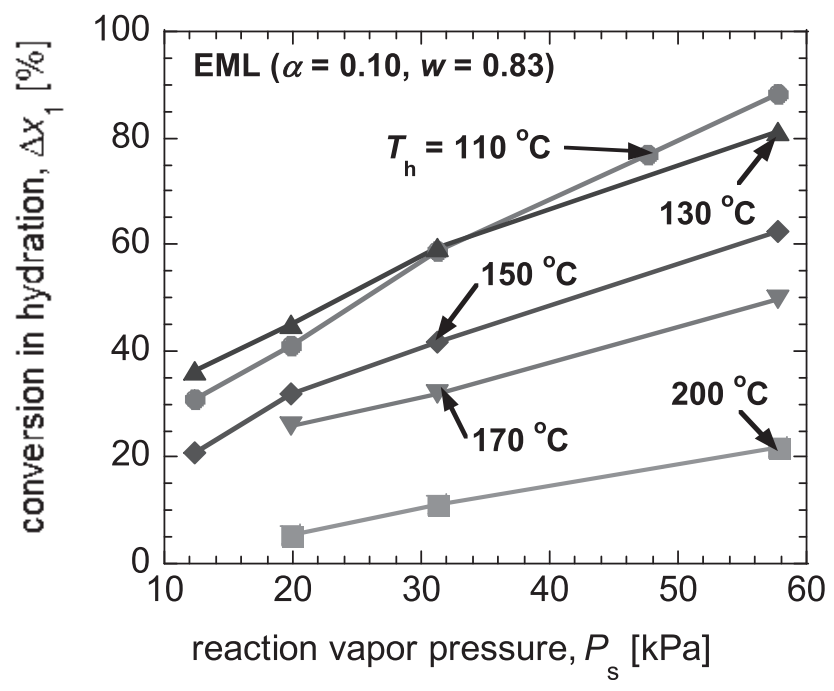

Fig. 11. Plots of $\Delta x_{1}$ vs. $P_{\mathrm{s}}$ for the EML composite $(\alpha=0.10, w=$ $0.83)$ at $T_{\mathrm{h}}=110-200^{\circ} \mathrm{C}$.

Table 1. The $\Delta x_{1}$ and $\Delta x_{2}$ values for the EML composite $(\alpha=0.10$, $w=0.83)$ at $T_{\mathrm{h}}=110-200^{\circ} \mathrm{C}, P_{\mathrm{s}}=12.3-57.8 \mathrm{kPa}$.

\begin{tabular}{|c|c|c|c|c|c|c|c|c|c|c|}
\hline \multirow{4}{*}{$P_{\mathrm{s}}[\mathrm{kPa}]$} & \multicolumn{10}{|c|}{ Hydration temperature, $T_{\mathrm{h}}\left[{ }^{\circ} \mathrm{C}\right]$} \\
\hline & \multicolumn{2}{|c|}{110} & \multicolumn{2}{|c|}{130} & \multicolumn{2}{|c|}{150} & \multicolumn{2}{|c|}{170} & \multicolumn{2}{|c|}{200} \\
\hline & $\Delta x_{1}$ & $\Delta x_{2}$ & $\Delta x_{1}$ & $\Delta x_{2}$ & $\Delta x_{1}$ & $\Delta x_{2}$ & $\Delta x_{1}$ & $\Delta x_{2}$ & $\Delta x_{1}$ & $\Delta x_{2}$ \\
\hline & \multicolumn{2}{|c|}{$[\%]$} & \multicolumn{2}{|c|}{$[\%]$} & \multicolumn{2}{|c|}{$[\%]$} & \multicolumn{2}{|c|}{$[\%]$} & \multicolumn{2}{|c|}{$[\%]$} \\
\hline 57.8 & 88.3 & 25.3 & 81.3 & 12.5 & 62.5 & 10.2 & 49.6 & 8.2 & 22.0 & 8.7 \\
\hline 47.4 & 76.9 & 16.4 & & & & & & & & \\
\hline 31.2 & 58.7 & 10.1 & 59.4 & 9.9 & 41.8 & 9.7 & 31.9 & 7.6 & 11.2 & 6.8 \\
\hline 19.9 & 41.1 & 8.1 & 44.4 & 7.9 & 31.8 & 7.5 & 25.7 & 5.5 & 5.4 & 4.6 \\
\hline 12.3 & 30.9 & 8.6 & 36.2 & 7.9 & 20.8 & 7.1 & & & & \\
\hline
\end{tabular}

ents a relation between $\Delta x_{1}$ and $P_{\mathrm{s}}$ at each hydration temperature studied. The $\Delta x_{1}$ value increased with increasing $P_{\mathrm{s}}$ at certain hydration temperature. The concentration of water at the interface between $\mathrm{LiBr}$ and $\mathrm{MgO}$ is thought to be increased with higher vapor pressures. The highest values of $\Delta x_{1}$ were achieved at $110^{\circ} \mathrm{C}$ for $P_{\mathrm{s}}>31.2 \mathrm{kPa}$ and at $130^{\circ} \mathrm{C}$ for $P_{\mathrm{s}} \leq 31.2 \mathrm{kPa}$. As the reaction conditions are identical, it was assumed that the rate of hydration is controlled by mass transfer for $P_{\mathrm{s}}<31.2 \mathrm{kPa}$ (poor water vapor diffusion in the EML composite), while it is controlled by heat transfer for $P_{\mathrm{s}}>31.2 \mathrm{kPa}$ (higher thermal conductivity of the EML composite). This result is identical to earlier research. ${ }^{9}$ Hence, it was thought that optimal hydration temperature would be $130^{\circ} \mathrm{C}$ at lower reaction pressure.

By using the data shown in Fig. 11, plot of $\ln \left(\Delta x_{1}\right)$ vs. $\ln \left(P_{\mathrm{s}} / P_{0}\right)$ at $T_{\mathrm{h}}=110-200^{\circ} \mathrm{C}$, as based on Eq. (13), is illustrated in Fig. 12. Straight lines with high correlation coefficients (0.99) were obtained in these temperature ranges studied. From the slopes of the lines, the coefficient $n$ could be determined for each $T_{\mathrm{h}}=110,130,150,170$ and $200^{\circ} \mathrm{C}$ of $0.69,0.53,0.70,0.62$ and 1.29 , while the values of $\ln (r)$ were $0.26,0.09,-0.06,-0.37$ and -0.75 (Table 2). The coefficient $n$ for the EML composite at $T_{\mathrm{h}}=110^{\circ} \mathrm{C}$ was close to the one obtained for pure $\mathrm{Mg}(\mathrm{OH})_{2}$ powder $\left(0.657\right.$ at $T_{\mathrm{h}}=$ $\left.110^{\circ} \mathrm{C}\right)$. It was also confirmed here that $\Delta x_{1}$ - value at $130^{\circ} \mathrm{C}$ is more sensitive to reaction pressure with respect to one at $110^{\circ} \mathrm{C}$ when $P_{\mathrm{s}}<31.2 \mathrm{kPa}$. Moreover, trend of curve at $200^{\circ} \mathrm{C}$ was different to compare with others. It might be because of higher temperature decreasing the reactivity. However, a further study at higher temperature is required

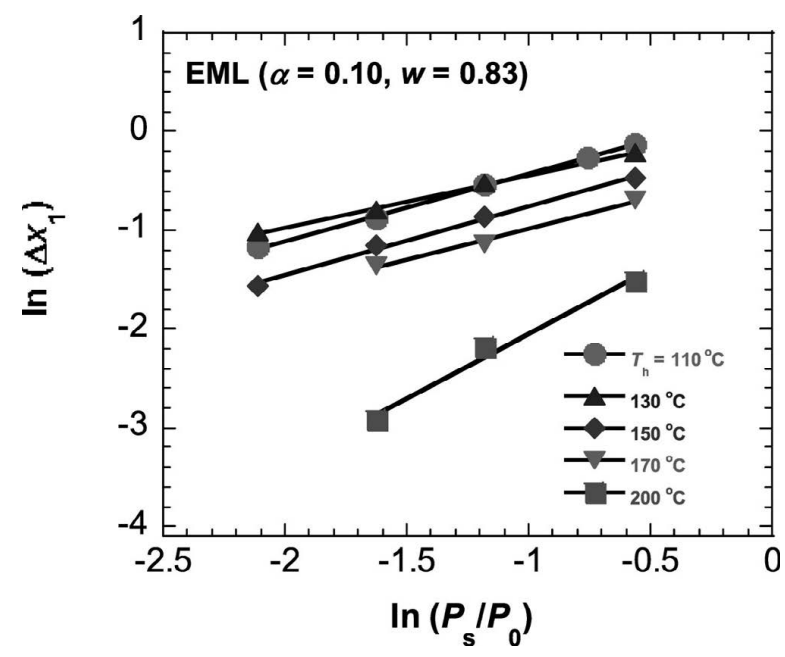

Fig. 12. Plots of $\ln \left(\Delta x_{1}\right)$ vs. $\ln \left(P_{\mathrm{s}} / P_{0}\right)$ for the EML composite $(\alpha=$ $0.10, w=0.83)$ at $T_{\mathrm{h}}=110-200^{\circ} \mathrm{C}$.

Table 2. The $n$ values for the EML composite $(\alpha=0.10, w=0.83)$ at $T_{\mathrm{h}}=110-200^{\circ} \mathrm{C}$.

\begin{tabular}{ccc}
\hline Temperature, $T_{\mathrm{h}}\left[{ }^{\circ} \mathrm{C}\right]$ & $n$ & $R_{1}$ \\
\hline 110 & 0.687 & 0.999 \\
130 & 0.530 & 0.998 \\
150 & 0.701 & 0.997 \\
170 & 0.622 & 0.994 \\
200 & 1.297 & 0.994 \\
\hline
\end{tabular}


to understand this phenomenon.

\subsection{Evaluation of Heat Output Capacity}

In this section, the heat output capacity, $q_{\text {out }}$, of the EML composite ( $\alpha=0.10, w=0.83$ ) were evaluated using Eq. (8). Therefore, $q_{\text {out }}-$ values, which calculated based on the data given in Fig. 11, are summarized in Table 3. Figure 13 shows heat output capacities of the EML composite $(\alpha=$ $0.10, w=0.83)$ at $P_{\mathrm{s}}=12.3-57.8 \mathrm{kPa}, T_{\mathrm{h}}=110-200^{\circ} \mathrm{C}$. Additionally, data of pure $\mathrm{Mg}(\mathrm{OH})_{2}$ powder under $57.8 \mathrm{kPa}$ at $T_{\mathrm{h}}=110-170^{\circ} \mathrm{C}$ is also shown in this figure. Here the solid symbols present the data of the EML composite whilst the open symbols indicate the data of pure $\mathrm{Mg}(\mathrm{OH})_{2}$ powder. The

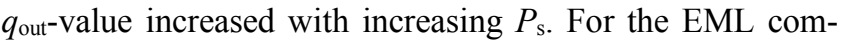
posite, $q_{\text {out }}$ values at $P_{\mathrm{s}}=57.8 \mathrm{kPa}$ after 140 min was 1168.7 $\mathrm{kJ} \mathrm{kg}_{\mathrm{EML}}{ }^{-1}$ which was $1.6,2.2$ and 2.8 times higher than those at $31.2,19.9$ and $12.3 \mathrm{kPa}$ at $110^{\circ} \mathrm{C}$, respectively. For the pure $\mathrm{Mg}(\mathrm{OH})_{2}$ powder, the $q_{\text {out }}$ values were calculated as $958.5,796.8,726.6$ and $323.4 \mathrm{~kJ} \mathrm{~kg}_{\mathrm{Mg}(\mathrm{OH})_{2}}{ }^{-1}$ at 110,130 , 150 and $170^{\circ} \mathrm{C}$, respectively over the $140 \mathrm{~min}$ of the process under $57.8 \mathrm{kPa}$. Those values corresponded to a 1.22 , 1.27, 1.07 and 1.92 times increased in the EML composite under identical hydration temperatures. A further observation from Fig. 13 was that the $q_{\text {out }}$ values attained at $130^{\circ} \mathrm{C}$ for $P_{\mathrm{s}} \leq 31.2 \mathrm{kPa}$ were higher than those at $110^{\circ} \mathrm{C}$ for the EML composite. The differences obtained were 6.6, 43.0

Table 3. Heat output capacities of the EML composite $(\alpha=0.10$, $w=0.83), T_{\mathrm{d}}=300^{\circ} \mathrm{C}, T_{\mathrm{h}}=110-200^{\circ} \mathrm{C}, P_{\mathrm{s}}=12.3-57.8$ $\mathrm{kPa}$, and vapor supply for $140 \mathrm{~min}$.

\begin{tabular}{ccccc}
\hline & \multicolumn{4}{c}{ Heat output capacity $q_{\text {out }}\left[\mathrm{kJ} \mathrm{kg}_{\mathrm{h}}\left[{ }^{\circ} \mathrm{C}\right]\right.$} \\
\cline { 2 - 5 } & $P_{\mathrm{s}}=57.8 \mathrm{kPa}$ & $P_{\mathrm{s}}=31.2 \mathrm{kPa}$ & $P_{\mathrm{s}}=19.9 \mathrm{kPa}$ & $P_{\mathrm{s}}=12.3 \mathrm{kPa}$ \\
\hline 110 & 1168.7 & 737.6 & 522.8 & 408.0 \\
130 & 1013.4 & 744.2 & 565.8 & 465.2 \\
150 & 782.8 & 539.6 & 411.0 & 281.9 \\
170 & 621.5 & 413.0 & 329.8 & \\
200 & 304.5 & 169.2 & 89.3 & \\
\hline
\end{tabular}

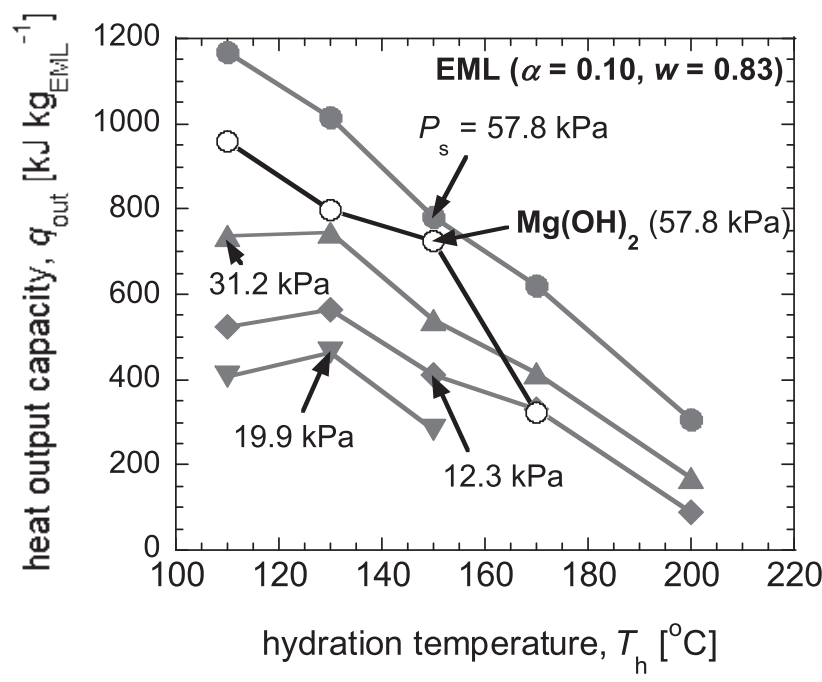

Fig. 13. Heat output capacities of the EML composite $(\alpha=0.10$, $w=0.83)$ at $P_{\mathrm{s}}=12.3-57.8 \mathrm{kPa}, T_{\mathrm{h}}=110-200^{\circ} \mathrm{C}$ and pure $\mathrm{Mg}(\mathrm{OH})_{2}$ at $P_{\mathrm{s}}=57.8 \mathrm{kPa}, T_{\mathrm{h}}=110-170^{\circ} \mathrm{C}$ after $140 \mathrm{~min}$. and $57.2 \mathrm{~kJ} \mathrm{~kg}_{\mathrm{EML}}{ }^{-1}$, respectively at $31.2,19.9$ and $12.3 \mathrm{kPa}$. Thus, it was concluded that the EML composites would likely have superior performance to pure $\mathrm{Mg}(\mathrm{OH})_{2}$ powder.

As mentioned earlier, latent heat storage using phase change materials (PCM) is feasible for waste heat recovery. For high temperature applications (around $300^{\circ} \mathrm{C}$ ) sodium nitrate, $\mathrm{NaNO}_{3}$, is a suitable material for latent heat storage among other alkali metal nitrates and nitrites. It has a high latent heat fusion of $175 \mathrm{~kJ} \mathrm{~kg}^{-1}$, and specific heat capacities of $1.5 \mathrm{~kJ}(\mathrm{~kg} \mathrm{~K})^{-1}$ in solid and $1.7 \mathrm{~kJ}(\mathrm{~kg} \mathrm{~K})^{-1}$ in liquid state around the melting temperature of $306^{\circ} \mathrm{C} .^{21)}$ Although this information suggests that the heat recover from waste gases by using the latent heat of the $\mathrm{NaNO}_{3}$ is acceptable, it is a possible to accumulate larger heat by using the EML composite $(\alpha=0.10, w=0.83)$. Because, the EML composites have to higher heat output capacities as shown in Fig. 13 in comparison with the $\mathrm{NaNO}_{3}$. As consequence, it is expected that the EML composites can be applied as chemical heat storage material in waste heat recovery from the iron-making process at a temperature range which has not been utilized effectively, namely, between 200 and $300^{\circ} \mathrm{C}$. ${ }^{1)}$ This offers new idea on combination of thermal energy storage based on the EML composite and iron making.

\section{Conclusions}

A novel candidate chemical heat storage material, called EML, was developed. The composite was obtained by mixing pure $\mathrm{Mg}(\mathrm{OH})_{2}$ with $\mathrm{LiBr}$ and expanded graphite (EG), which offer higher reactivity and thermal conductivity, respectively. The effects of mass mixing ratios of EG - to $\mathrm{Mg}(\mathrm{OH})_{2}, w$, on dehydration and hydration was investigated by a thermogravimetric method. The dehydration rate constant, $k_{\mathrm{d}}$, decreased as the $w$-value rose, which indicated that the thermal conduction provided by EG played a significant role in the dehydration process. In the case of hydration, the peak of the hydration rate constant, $k_{\mathrm{h}}$, was observed at $w=$ 0.83 . As a result, the $w$ value of 0.83 was the optimal mass mixing ratio. Furthermore, the influences of reaction temperature and vapor pressure on the hydration rate of the EML composite $(w=0.83)$ were investigated, with result that the mole reacted fraction of hydration increased as the reaction temperature decreased or as the vapor pressure increased, which indicated that temperature and vapor pressure played a significant role in the reactivity enhancement. Heat output capacity per unit initial weight of the EML composite was calculated as $1168.7 \mathrm{~kJ} \mathrm{kgEML}^{-1}$ at a hydration temperature of $110^{\circ} \mathrm{C}$ and reaction vapor pressure of $57.8 \mathrm{kPa}$. This value was 1.2 times higher than that of pure $\mathrm{Mg}(\mathrm{OH})_{2}$ powder $\left(958.5 \mathrm{~kJ} \mathrm{~kg}_{\mathrm{Mg}(\mathrm{OH})_{2}}{ }^{-1}\right)$. Thus, it is expected that the EML composites can be applied as chemical heat storage material in waste heat recovery from the iron-making process at a temperature range which has not been utilized effectively, namely, between 200 and $300^{\circ} \mathrm{C}$.

\section{Acknowledgments}

This study received financial support from a Grant-in-Aid for Scientific Research (B) \#24360404 from the Ministry of Education, Culture, Sports, Science and Technology (MEXT), Japan. 


\section{Nomenclature}

$k=$ reaction rate constant $\left[\mathrm{s}^{-1}\right]$

$M \quad=$ molecular mass $\left[\mathrm{kg} \mathrm{mol}^{-1}\right]$

$m \quad=$ mass $[\mathrm{kg}]$

$n \quad=$ reaction coefficient $[-]$

$P \quad=$ vapor pressure $[\mathrm{kPa}]$

$r=$ constant that partially depends on the rate of grain growth $[-]$

$R_{l} \quad=$ correlation coefficient $[-]$

$T \quad=$ temperature $[\mathrm{K}]$

$t=$ measurement time $[\mathrm{s}]$

$q \quad=$ heat output capacity $\left[\mathrm{kJ} \mathrm{kg}^{-1}\right]$

$x=$ reacted mole fraction $[\%]$

$w \quad=$ mixing mass ratio $[-]$

\section{Greek letters}

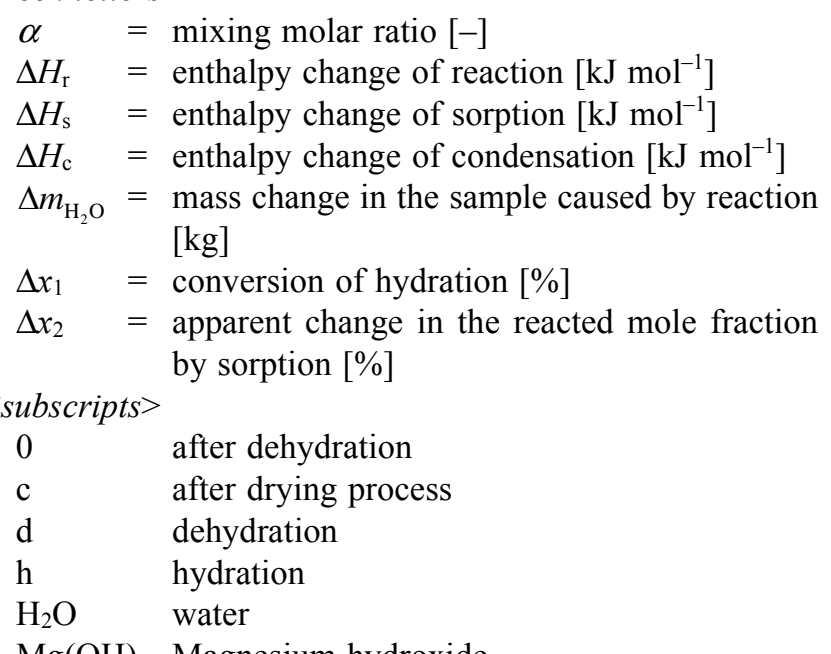

s saturation

$\mathrm{V} \quad$ end of the water supply

out output

\section{REFERENCES}

1) K. Kabeya: Proc. Symp. on Technology of the Waste Heat Energy, Vol. 2, AIST, Tokyo, (2012), 67.

2) I. Dincer and M. A. Rosen: Thermal Energy Storage Systems and Applications, Wiley, London, (2002).

3) T. Steinparzer, M. Haider, A. Fleischander, A Hampel, G. Enickl and F. Zauner: J. Phys. Conf. Ser., 395 (2012), 012158.

4) T. Akiyama, T. Shimada, E. Kasai and J. Yagi: Proc. China-Japan Int. Academic Symp. on Environmental Problem in Chinese Iron-Steelmaking Industries and Effective Technology Transfer, Tohoku University Press, Sendai, Japan, (2000), 53.

5) The Japan Iron and Steel Federation: Unused Energy in the Integrated Steelworks, JISF, Tokyo, (1992), 10.

6) M. Sakakibara: Tetsu-to-Hagané, 76 (1990), 1587.

7) Y. Kato, N. Yamashita, K. Kobayashi and Y. Yoshizawa: Appl. Therm. Eng., 16 (1996), 853.

8) Y. Kato, K. Kobayashi and Y. Yoshizawa: Appl. Therm. Eng., 18 (1998), 85.

9) M. Zamengo, J. Ryu and Y. Kato: Appl. Therm. Eng., 69 (2014), 29.

10) R. Olives and S. Mauran: Transport Porous Med., 43 (2001), 377.

11) K. Fujioka, K. Hatanaka and Y. Hirata: Appl. Therm. Eng., 28 (2008), 304.

12) M. Zamengo, J. Ryu and Y. Kato: Appl. Therm. Eng., 61 (2013), 853.

13) M. Odtsetseg, J. Ryu and Y. Kato: Appl. Therm. Eng., 63 (2014), 170.

14) M. Odtsetseg, J. Ryu and Y. Kato: JCEJ, 47 (2014), 595

15) M. Odtsetseg, J. Ryu and Y. Kato: Proc. 4th Int. Symp. on Innovative Nuclear Energy Systems, Organizing Committee of INES-4, Tokyo, (2013).

16) R. S. Gordon and W. D. Kingery: J. Am. Ceram. Soc., 50 (1967), 8.

17) H. Ishitobi, K. Uruma, M. Takeuchi, J. Ryu and Y. Kato: Appl. Term. Eng., 50 (2013), 1639.

18) O. Levenspiel: Chemical Reaction Engineering, Wiley, New York, (1999), 580.

19) S. Tae Kim, J. Ryu and Y. Kato: Prog. Nucl. Energ., 53 (2011), 1027.

20) Y. Kato, J. Nakahata and Y. Yoshizawa: J. Mater. Sci., 34 (1999), 475.

21) D. Laing, T. Bauer, D. Lehmann and C. Bahl: J. Sol. Energ. Eng., 132 (2010), 021011-1. 